\title{
ARTIKEL AUDIT SISTEM INFORMASI PADA PT TUNAS DWIPA MATRA LAMPUNG MENGGUNAKAN PENDEKATAN COBIT 4.1
}

\author{
Marina Manda Sari \\ 155100046 \\ Universitas Mitra Indonesia, Sistem Informasi \\ Marinamandasari.student@umitra.ac.id
}

\begin{abstract}
ABSTRAK
Teknologi Informasi berkembang dengan cepat dan sangat berpengaruh terhadap peningkatan efisiensi derta efektivitas kegiatan bisnis dengan mengembangkan perusahaan. Tujuan dari penelitian ini adalah mengevaluasi penilaian dan membuat rekomendasi berdasarkan analisis maturity level terhadap TI di PT Tunas Dwipa Matra Lampung sesuai standar.

Standar ini digunakan karena menggunakan standar kontrol umum untuk pengendalian terhadap teknologi informasi dan memiliki parameter yang dapat membantu penilaian resiko suatu perusahaan dengan memggunakan maturity models. Penelitian ini menghasilkan temuan bahwa teknologi informasi di PT Tunas Dwipa Matra Lampung dengan menggunakan kerangka kerja COBIT 4.1 memiliki maturity level sebesar 4,02 .
\end{abstract}

Kata kunci :audit sistem informasi, maturity level, control, COBIT 


\section{A. PENDAHULUAN}

Audit merupakan sebuah kegiatan yang melakukan pemerikasaan untuk menilai dan mengevaluasi sebuah aktivitas atau objek seperti implementasi pengendalian internal pada sistem informasi pada PT Tunas Dwipa Matra yang pekerjaannya ditentukan oleh manajemen atau proses fungsi akuntansi yang membutuhkan improvement. Proses auditing telah menjadi sangat rapi di Amerika Serikat, khususnya pada bidang profesional accounting association. Akan tetapi, baik profesi audit internal maupun eksternal harus secara terus menerus bekerja keras untuk meningkatkan dan memperluas teknik, karena profesi tersebut akan menjadi tidak mampu untuk mengatasi perkembangan dalam teknologi informasi dan adanya tuntutan yang semakin meningkat oleh para pemakai informasi pada PT Tunas Dwipa Matra.

Audit sistem informasi adalah proses pengumpulan dan penilaian bukti - bukti untuk menentukan apakah sistem komputer dapat mengamankan aset, memelihara integritas data, dapat mendorong pencapaian tujuan organisasi secara efektif dan menggunakan sumberdaya secara efisien". Ron Weber $(1999,10)$ mengemukakan bahwa audit sistem informasi adalah :

" Information systems auditing is the process of collecting and evaluating evidence to determine whether a computer system safeguards assets, maintains data integrity, allows organizational goals to be achieved effectively, and uses resources efficiently".

Audit sistem informasi diperlukan oleh perusahaan dalam pencapaian tujuan perusahaan, oleh karena itu perusahaan harus membuat prosedur pengendalian dalam menjaga aset perusahaan dan memeriksa 
pengendalian tersebut dengan menguji pengendalian. Menguji pengendalian digunakan untuk mengevaluasi apakah telah berjalan sesuai dengan prosedur atau tidak. 


\section{B. TINJAUAN PUSTAKA}

a. Pengertian Audit Sistem Informasi

Alvin A. Arens dan James K.Loebbecke

"Auditing is the accumolatuin and evaluation of evidence about information to dtermine and report on the degree of correspondence between the information and establishe criteria. Examining ought to be finished by a skillful autonomous individual".

Mengacu pada definisi diatas maka audit ialah pengumpulan dan evaluasi terhadap bukti untuk menentukan derajat kesesuaian anatar informasi dan criteria yang telah ditetapkan. Hal ini berarti dalam pelaksanannya evaluasi dilakukan mengacu pada sejumlah criteria tertentu untuk menentukan derajat kinerja yang telah dicapai.

\section{b. Pengertian COBIT}

COBIT merupakan standar control umum untuk pengendalian terhadap teknologi informasi. COBIT 4.1 menyediakan framework dan paraf 2 yang membantu penilaian resiko suatu perusahaan dengan menggunakan maturity models. Maturity models sebagai alat ukur dalam mengetahui kondisi proses IT yang digunakan perusahaan saat ini. Maturity models dikelompokan dari level 0 atau non-existen (belum tersedia) hingga 5 atau optimized. Level maturity models dibuat dengan tujuan supaya pihak manajemen dapat dengan mudah memahami dan mengidentifikasi setiap proses teknologi informasi yang ada dalam suatu perusahaan. 
- Referensi

1. Oktaviani,lilis.audit teknologi informasi pada PT Internasional. Lampung :2013

2. Alvin A. Arens and James K.Loebbecke.auditityng an Integrated Approach. International Edition. Seventh Edition. New jersey :PRENTICE-HILL IN, 1997

3. Gondodiyoto,Santoyo dan Henny H. Audit SI lanjutan (standar, panduan, dan prosedur dari ISACA) Jakarta: mitra wacana media,2017.

4. Mukhtar, Masjono Ali. Audit Sistem Informasi. Jakarta: PT Rineka cipta, 2002.

5. Ron, Weber. Information Control And Audit .prentice-hall, inc: new jersey :1999.

\section{STUDI KASUS}

Audit Sitem Informasi Pada PT TUNAS DWIPA MATRA menggunakan pendekatan COBIT 4.1

\section{DISKUSI}

Audit pada dasarnya adalah proses sistematis dan objektif dalam memperolehdan mengevaluasi bukti-bukti tindakan ekonomi, guna memberikan asersi dan menilai seberapa jauh tindakan ekonomi sudahsesuai dengan kriteria berlaku, dan mengkomunikasikan hasilnya kepada pihak terkait.

Secara umum dikenal tiga jenis audit; Audit keuangan, audit 
operasional danaudit sistem informasi(teknologi informasi). Audit TI merupakan proses pengumpulan dan evaluasi bukti-bukti untukmenentukan apakah sistem komputer yang digunakan telah dapat melindungi aset milik organisasi,mampu menjaga integritas data, dapat membantu pencapaian tujuan organisasi secara efektif, sertamenggunakan sumber daya yang dimiliki secara efisien. Audit SI/TI relatif baru ditemukan dibanding auditkeuangan, seiring dengan meningkatnya penggunan TI untuk mensupport aktifitas bisnis.

\subsection{Audit Data Perusahaan}

Data dapat menyebabkan kebutuhan sumber daya menjadi kritis untuk keberlangsungan operasional organisasi (baik untuk memberikan gambaran masa lalu,masa kini dan masa yang akan datang)

Jika data akurat, maka organisasi akan mempunyai kemampuan untuk beradaptasi dan bertahan dalam lingkungan yang berubah. Jika tidak (data hilang), maka organisasi akan mengalami kehilangan data yang cukup penting.

' Contoh jika data master barang di suatu toko swalayan rusak, maka kasirtidak dapat melakukan transaksi pembelian yang dilakukan oleh konsumen

\subsection{Audit Pengambilan Keputusan}

' Untuk membuat keputusan yang berkualitas dan dapat dipercaya, maka perlu di dukung oleh data yang akurat melalui sistem informasi berbasis komputer

'Termasuk : deteksi, investigasi, dan koreksi proses yang diluar kontrol (connection of out-of- control process)

' Akibat data yang salah akan mempunyai dampak terhadap minat investor terhadap perusahaan. Contoh : jika penyediaan laporan keuangan salah (inaccurate financial information), maka investor akan membatalkan 
atas keputusan investasinya

'Penting juga diperhatikan tentang 'aturan-aturan keputusan yang akurat(accurate decision rules).

' Contoh jika aturan pengambilan keputusan (decision rule) dalam sistem pakar untuk mendukung diagnosis, salah, mengakibatkan dokter akan salah dalam memberikan keputusan / pemberian resep kepada pasiennya, ini akan berakibat fatal

\subsection{Audit Keamanan Komputer}

'Sebagian besar sebab yang mendorong pengembangan fungsi audit SI di perusahaan adalah akibat seringnya terjadi penyalahgunaan komputer

'Penyalahgunaan komputer : "segala kejadian yang berhubungan dengan teknologi komputer yang mengakibatkan kerugian pada korban atau mengakibatkan kehilangan yang diakibatkan oleh pelaku kejahatan untuk mencari keuntungan"

\subsection{Tujuan Audit SI}

- Pengamanan aset

- Efektifitas sistem

- Efisiensi sistem

- Ketersediaan (Availability)

- Kerahasiaaan (Confidentiality)

- Kehandalan (Realibility)

- Menjaga integritas data

\subsection{Tahapan Audit}
a) Subjek Audit
b) Sasaran audit
c) Jangkauan audit
d) Rencana pre-audit
e) Prosedur audit dan langka-langkah pengumpulann bukti audit
f) Prosedur untuk evaluasi 
g) Laporan hasil audit

\section{E. KESIMPULAN}

Audit adalah proses mengumpulkan dan mengevaluasi fakta untuk memutuskan apakah sistem komputer yang merupakan aset bagi perusahaan terlindungi, integritas data terpelihara, sesuai dengan tujuan organisasi untuk mencapai efektifitas, dan efisiensi dalam penggunaan sumber daya. Audit teknologi sistem informasi memiliki ruang lingkup yang terdiri dari data perusahaan, pengambilan keputusan, keamanan komputer. Tujuan audit si terdiri pengamanan aset, efektifitas sistem, Efisiensi sistem, Ketersediaan (Availability), Kehandalan (Realibility), Menjaga integritas data.

\section{F. REFERENSI}

1. Oktaviani,lilis.audit teknologi informasi pada PT Internasional. Lampung :2013

2. Alvin A. Arens and James K.Loebbecke.auditityng an Integrated Approach. International Edition. Seventh Edition. New jersey :PRENTICE-HILL IN, 1997

3. Gondodiyoto,Santoyo dan Henny H. Audit S/ lanjutan (standar, panduan, dan prosedur dari ISACA) Jakarta: mitra wacana media,2017.

4. Mukhtar, Masjono Ali. Audit Sistem Informasi. Jakarta: PT Rineka cipta, 2002. 
5. Ron, Weber. Information Control And Audit .prentice-hall, inc: new jersey :1999. 